\title{
Metanaration in the Novel Roro Jonggrang by Budi Sardjono: Ethnocriticism Perspective
}

\author{
Arisni Khoilifatu Amalia Shofiani ${ }^{1}$, Haris Supratno ${ }^{2}$, Setya Yuwana ${ }^{3}$, Udjang Pairin ${ }^{4}$, \\ Darni $^{5}$, Suhartono $^{6}$ \\ \{arisni.19032@mhs.unesa.ac.id ${ }^{1}$, harissupratno@unesa.ac.id², setyayuwana@unesa.ac.id ${ }^{3}$, \\ udjangpairin@unesa.ac.id ${ }^{4}$; darni@unesa.ac.id ${ }^{5}$; suhartono@unesa.ac.id ${ }^{6}$ \} \\ Universitas Negeri Surabaya, Surabaya, Indonesia
}

\begin{abstract}
The novel Roro Jonggrang by Budi Sardjono was a novel that tells of the feud between two kingdoms, Pengging and Prambanan, in the period before the legend of Roro Jonggrang and Bandung Bandawasa. This novel was interesting to study because the general public knew more about the legend of the construction of Prambanan Temple, and only few people knew about how Roro Jonggrang and Bandung Bandawasa met. In this article, the authors focus on the discussion on metanarations in the novel Roro Jonggrang. To reveal the metanarations, the authors use Krupat's ethnocriticism. This study aims to find and describe the metanarations in the novel Roro Jonggrang. This research used a qualitative approach. The data source was the novel Roro Jonggrang. The results showed that there were metanarations in the novel.
\end{abstract}

Keywords: metanaration, novels, ethnocriticism.

\author{
Metanarasi dalam Novel Roro Jonggrang Karya Budi Sardjono: Perspektif \\ Etnokritik
}

\begin{abstract}
Abstrak. Novel Roro Jonggrang karya Budi Sardjono adalah novel yang menceritakan perseteruan dua kerajaan, Pengging dan Prambanan, pada masa sebelum terjadinya legenda Roro Jonggrang dan Bandung Bandawasa. Novel ini menarik untuk diteliti karena masyarakat pada umumnya lebih mengetahui legenda tentang dibangunnya Candi Prambanan, dan tidak banyak yang tahu tentang bagaimana Roro Jonggrang dan Bandung Bandawasa bertemu. Dalam tulisan ini, peneliti memfokuskan pembahasan pada metanarasi dalam novel Roro Jonggrang. Untuk mengungkap metanarasi tersebut, peneliti menggunakan teori etnokritik dari Krupat. Penelitian ini bertujuan menemukan dan mendeskripsikan metanarasi dalam novel Roro Jonggrang. Penelitian ini menggunakan pendekatan kualitatif. Sumber datanya adalah novel Roro Jonggrang. Hasil penelitian menunjukkan terdapat metanarasi dalam novel tersebut.
\end{abstract}

Kata kunci: metanarasi, novel, etnokritik.

\section{Pendahuluan}

Selama ini masyarakat mendengar legenda Roro Jonggrang dan Bandung Bandawasa lebih terpusat pada kegagalan Bandung Bandawasa membangun seribu candi untuk Roro 
Jonggrang. Namun, tidak banyak yang mengetahui bagaimana keduanya bertemu. Oleh karena itu, sangat mungkin khalayak pembaca akan mendapati sisi lain dari kisah tersebut ketika membaca novel Roro Jonggrang karangan Budi Sardjono.

Novel Roro Jonggrang menceritakan kisah sejarah perseteruan antara dua kerajaan yang bertetangga, Kerajaan Prambanan dan Pengging. Kerajaan Prambanan terletak di kaki Gunung Merapi, dipimpin oleh Gusti Prabu Baka Geni dan Gusti Roro Jonggrang, sementara Kerajaan Pengging terketak di kaki Gunung Merbabu, dipimpin oleh Prabu Damar Maya. Hubungan kerajaan Prambanan dan Pengging baik. Namun demikian, hubungan keduanya sebenranya menyimpan bara yang setiap saat bisa mengobarkan api peperangan. Kehidupan Prambanan lebih baik daripada Pengging yang hanya mengandalkan pertanian sebagai fondasi bagi kehidupan mereka. Novel ini memotret perseteruan kedua kerajaan jauh sebelum legenda pembangunan Candi Prambanan, sehingga mengungkap pula kisah pertemuan antara Roro Jonggrang dan Bandung Bandawasa.

Sebagaimana ada pada teks pada umumnya, novel Roro Jonggrang juga memuat metanarasi, yakni sesuatu yang tidak terlihat atau tidak pernah diungkap di dalamnya. Penelitian ini bertujuan mengkaji novel Roro Jonggrang menggunakan teori etnokritik dari Krupat untuk mengungkap metanarasi yang terkandung di dalam novel tersebut. Menurut, Krupat etnokritis (etno berarti budaya) merupakan kritik terhadap etnis populer. Gagasan ini berangkat dari pengamatan terhadap masyarakat Amerika Serikat, di mana orang-orang kulit putih mayoritas dan dominan, namun terdapat warga Amerika yang berkulit hitam (Krupat, 19992: 4) [4].

Legenda Roro Jonggrang sendiri telah menarik perhatian atau menginspirasi banyak peneliti untuk melakukan penelitian atau pengkajian, bahkan menjadi sumber ide untuk menciptakan batik motif wayang yang digunakan pada busana kebaya [5]. Jamal [3] telah melakukan penelitian yang bertujuan untuk mengetahui struktur mitos dalam novel Sang Nyai 1 karya Budi Sardjono. Metode yang digunakan dalam penelitian tersebut berupa metode deskriptif kualitatif. Hasil penelitiannya menunjukkan bahwa struktur mitos yang terdapat pada novel tersebut hanya ada pada tokoh Kesi dan Tokoh Petruk.

Berbeda dengan Jamal yang berusaha mengkaji struktur mitos yang ada di dalam sebuah karya sastra, Ismail [2] dalam penelitiannya justru berusaha membuktikan suatu karya sastradalam hal ini novel-novel Shahnon Ahmad - sebagi produksi budaya suatu masyarakatdalam hal ini masyarakat Melayu-yang berhubungan erat dengan intelektual sistem sosial yang bekerja pada masyarakat tersebut. Dalam penelitian tersebut, novel-novel Shahnon Ahmad digunakan sebagai medium untuk memahami cita-cita masyarakat Melayu dalam aspek psikososial, sosioekonomi dan sosiopolitik ketika berhadapan dengan sistem tertentu. Melalui pengkajian atas karya-karya tersebut juga dapat dibangun pemahaman tentang cara berpikir, struktur kebudayaan, dan perilaku dalam sebuah masyarakat. Dengan kata lain, penelitian Ismail berusaha mengungkap metanarasi yang terdapat pada novel-novel Shahnon Ahmad untuk dapat memahami sistem sosial dan kebudayaan masyarakat Melayu.

Penelitian atas metanarasi di balik karya sastra juga dilakukan oleh Fitriana [1]. Ia berusaha membangun pemahaman tentang identitas budaya dalam novel Kembar Keempat karya Sekar Ayu Asmara. Penelitiannya menggunakan metode analisis deskriptif, dengan tujuan untuk mengkaji aspek-aspek postmodernisme sebagai metanarasi dari novel Kembar Keempat. Hasil penelitiannya menunjukkan bahwa di dalam novel karya Sekar Ayu Asmara tersebut terdapat identitas budaya postmodernis, yakni agama sebagai pembebas dan pembaharu, pengelabuan identitas dan penopengan sebagai pembentukan kesan, serta adopsi budaya sebagai ekspresi kebudayaan yang tidak terikat ruang. 
Berbeda dengan penelitian-penelitian sebelumnya, penelitian ini memfokuskan pengaplikasian teori etnokritis pada metanarasi yang terdapat dalam novel Roro Jonggang karya Budi Sardjono. Penelitian ini merupakan ikhtiar bersahaja dari penulis sebagai sumbangsih bagi kritik sastra di Indonesia, terutama dalam ranah pengkajian metanarasi.

\section{Metode}

Penelitian ini merupakan penelitian kualitatif. Melalui perencanaan yang diimplementasikan dalam proses penelitian, dapat ditentukan kebenaran atau kesalahan penjelasan terkait objek yang ditelaah (Masrhall dan Rossman, 2006: 3) [7]. Penelitian kualitatif adalah penelitian yang berusaha memahami suatu objek pada ruang-waktu alamiahnya, menggunakan data deskriptif, mementingkan proses, dan terfokus pada konteks, serta mengutamakan interpretasi dalam rangka menemukan makna. Metode kualitatif digunakan karena sebagaimana penelitian sastra pada umumnya, data penelitian ini juga tidak berupa angka-angka. Data penelitian yang digunakan berupa data deskriptif sesuai fokus penelitian. Dalam hal ini, peneliti bertindak sebagai instrumen penelitian.

Sumber data dalam penelitian ini adalah novel Roro Jonggrang (RJ) karya Budi Sasrdjono. Data yang digunakan adalah segala tulisan yang terdapat di dalam novel tersebut, baik berupa kata, kalimat, maupun paragraf. Data tersebut kemudian penulis analisis sesuai kebutuhan penelitian, yaitu untuk mengungkap metanarasi yang dikandungnya.

Sesuai dengan sumber dan jenis datanya, teknik pengumpulan data dalam penelitian ini adalah teknik baca dan catat. Adapun analisis data dilakukan dengan analisis isi, yaitu menganalisis isi novel RJ untuk mendapatkan penafsiran metanarasi. Langkah-langkah analisis yang diterapkan di dalam penelitian ini adalah sebagai berikut:

1) Peneliti mengumpulkan dan mengidentifikasi data pada novel RJ. Untuk memudahkan peneliti dalam menganalisis dan menelusuri koherensi antara sumber data dengan penjabaran, maka peneliti melakukan pengodean.

Contoh:

"Hati Prabu Damar Maya sering bergetar apabila menyebut nama kerajaan tetangganya itu. Apalagi jika mengingat siapa yang duduk di atas tahta kerajaan Prambanan. Prabu Baka Geni!" (RJ: 11) [8]

Keterangan:

RJ : Roro Jonggrang

11 : nomor halaman

2) Peneliti menganalisis data yang telah diidentifikasi sebelumnya dengan menggunakan konsep metanarasi yang diambil dari teori etnokritis Krupat.

3) Peneliti melakukan penarikan simpulan sebagai kelanjutan dari penyajian dan hasil analisis data.

\section{Hasil dan Pembahasan}

Bagian ini menguraikan hasil penelitian dan pembahasan terhadap metanarasi pada novel RJ dengan menggunakan perspektif etnokritis dari Krupat. Data pertama mengungkap 
metanarasi terkait hubungan antara dua kerajaan bertetangga yang diceritakan dalam novel, yakni Pengging dan Prambanan. Disebutkan bahwa:

"Pengging dan Prambanan. Tetangga dekat, namun hampir tidak pernah bertegur sapa. Sepertinya, masing-masing menyimpan keinginan yang dirahasiakan. Tidak ada yang tahu apa sesungguhnya yang tersimpan di hati kedua penguasa Kerajaan itu. Karena selama ini memang saling diam." (RJ: 10) [8]

Sesuai dengan teori Krupat, metanarasi dapat mengungkapkan apa yang tidak biasanya diketahui oleh khalayak umum, di mana sesuatu yang kecil dapat menjadi perkara besar [4]. Paragraf di atas menggambarkan sesuatu yang selama ini sudah diketahui, yakni bahwa Prambanan dan Pengging merupakan dua kerajaan yang bertetangga satu sama lain. Namun demikian, juga terdapat sesuatu yang tidak diketahui secara umum, di mana kedua kerajaan memiliki rahasia tersendiri.

"Tetapi siapa yang mau ngalah terus-menerus? Di jagat raya ini. Tak seorang raja pun yang mau mengalah terus-menerus terhadap kekuasaan raja lain. Di samping menyakitkan hati, hal itu tidak memberikan martabat, baik untuk sang raja, keluarga, dan rakyatnya. Hanya raja yang bodoh dan lemah yang mau mengalah terusmenerus dan tidak mencoba mengadakan perlawanan!’”(RJ: 13) [8]

Paragraf di atas menyiratkan adanya perasaan tidak ingin kalah sebagai salah satu perwujudan dari martabat. Seorang raja, sebagai sosok yang memiliki kekuasaan, dituntut untuk berikap bijak dan mengutamakan kepentingan kerajaannya. Termasuk dalam berelasi dengan penguasa dari kerajaan lain. Dalam hal ini, raja yang baik adalah raja yang dapat bersikap bijak terhadap semua orang, termasuk rakyatnya. Sikap dan kebijakan sang raja, tidak hanya demi dirinya pribadi, melainkan juga merepresentasikan seluruh kerajaan dan rakyatnya.

"Karena itulah, Prambanan tidak mengizinkan Pengging mengambil daerah di Kaki Gunung Merapi, walau hanya sebagian. Prambanan tetap bersikeras tidak akan membiarkan wilayah Kaki Gunung Merapi menjadi bagian dari Pengging. Karena Prambanan juga tidak berniat mencaplok daerah itu untuk disatukan ke dalam kekuasaannya." (RJ: 15) [8]

Paragraf di atas mengungkapkan bahwa Prambanan dan Pengging memiliki perselisihan. Tidak banyak masyarakat yang tahu akan hal itu, sehingga dapat dikatakan sebagai metanarasi.

“... rakyat di sana dibebaskan membayar upeti. Mereka bebas bepergian tanpa harus membayar pajak. Mereka bebas melakukan perdagangan dengan rakyat dari kedua kerajaan. Masing-masing tidak boleh mengganggu wilayah kaki Gunung Merapi. Biarkan wilayah itu menjadi daerah tak bertuan. Yang penting, rakyat di sana tidak berkeinginan untuk membangun pusat kekuasaan apalagi sampai mendirikan kerajaan kecil.” (RJ: 15-16) [8]

Paragraf di atas menceritakan bagaimana daerah kaki Gunung Merapi, sekalipun tidak diklaim sebagai bagian dari kekuasaan Prambanan maupun Pengging, namun tetap menjadi 
sebab perselisihan kedua kerajaan. Kedua kerajaan tidak memungut upeti dari rakyat setempat, dan tidak saling berselisih memperebutkan wilayah tersebut. Sebagaimana kita ketahui selama ini, rakyat wajib membayar atau menyetorkan upeti kepada kerajaan. Namun, hal berbeda terjadi pada daerah di kaki Gunung Merapi; rakyat setempat dibebaskan dari membayar upeti. Dengan demikian, mereka tetap menjadi daerah bebas, "daerah tak bertuan." Namun demikian, mereka tetap berada di bawah pengaruh dan bayang-bayang dua kerajaan yang mengapitnya, yang tidak akan membiarkan mereka untuk mendirikan kerajaan berdaulat tersendiri. Metanarasi yang berbeda dapat kita temukan pada paragraf berikut ini:

“... karena ia belum punya seseorang pun kekasih. Belum ada gadis Pengging yang bisa membuka pintu hatinya untuk urusan asmara, pintu hati lelaki itu konon seperti terbuat dari baja. Tidak bisa dibuka." (RJ: 44) [8]

Paragraf di atas menggambarkan bahwa hati seorang lelaki sangat keras layaknya baja. Namun demikian, jika kita bisa mengambil hatinya, maka seorang lelaki akan menuruti kemauan kita. Dengan kata lain, hati lelaki sebenarnya tidak selalu keras baja. Itulah yang terkadang tidak bisa dimengerti oleh banyak orang. Sesuai dengan metanarasi Krupat, hal ini menunjukkan bahwa yang kita ketahui selama ini belum tentu benar. Perlu adanya narasi kecil untuk mengetahui kenapa hati lelaki bersifat keras karena tidak semua lelaki demikian.

\section{Simpulan}

Berdasarkan analisis data dan pembahasan metanarasi berdasarkan etnokritik Krupat, dapat disimpulkan bahwa novel RJ juga menyiratkan berbagai metanarasi, di mana sesuatu yang tidak terlihat dari kacamata yang dominan atau yang selama ini diketahui, ternyata dapat diungkap sebagai hal yang signifikan dalam memahami suatu permasalahan, seperti hubungan dua kerajaan bertetangga yang diceritakan di dalam novel RJ, Pengging dan Prambanan.

\section{Referensi}

[1] Fitriana, DN. Identitas Budaya dalam Novel Kembar Keempat Karya Sekar Ayu Asmara: Kajian Postmodernisme. Jurnal Academica. Vol. 1 No. 1, Januari- Juni 2017 ISSN: 2579-9703 (P) | ISSN: 2579-9711 (E)

[2] Ismail, A. Novel-novel Shahnon Ahmad dalam Perspektif Etnografi Semantik. Jurnal Antarabangsa Persuratan Melayu (RUMPUN)International Journal of The Malay LettersJilid 6/Jan/2018, 130ISSN:2289-5000.

[3] https://rumpunjurnal.com/jurnal/index.php/rumpun/article/view/36/43

[4] Jamal. Analisis Mitos Dalam Novel Sang Nyai 1 Karya Budi Sardjono (Teori LeviStrauss).https://digilibadmin.unismuh.ac.id/upload/1048-Full_Text.pdf

[5] Krupat, A. Ethnocriticism.Berkeley: University of California Press. 1992.

[6] Lestari, R. Cerita Roro Jongrang sebagai Ide Penciptaan Kain Batik Motif Wayang Menjadi Busana Kebaya. Institutional Repository: Isi Surakarta. 2018. http://repository.isi-ska.ac.id/2939/

[7] Lyotard, JF.The Postmodern Condition:A Report on Knowledge. USA: University of Minnesota Press. 1984.

[8] Marshall C, Gretchen BR. Designing Qualitative Research. London: Sage Publications. 2006.

[9] Sardjono B. Roro jonggrang. Yogyakarta: DIVA Press. 2013. 